\title{
Synergy of contemporary architecture and materials science
}

\author{
Petro Rychkov ${ }^{1}$, Nataliya Lushnikova ${ }^{2}$ \\ ${ }^{1}$ Department of Conservation of Built Heritage, \\ Faculty of Civil Engineering and Architecture, Lublin University of Technology, Lublin, Poland, \\ e-mail:p.rychkov@pollub.pl \\ ${ }^{2}$ Department of Architecture and Environmental Design, \\ National University of Water and Environmental Engineering, Rivne, Ukraine, \\ e-mail:n.v.lushnikova@nuwm.edu.ua
}

\begin{abstract}
The article gives coverage on the levels of synergetic interaction between architecture and materials science. There are discussed some main benefits and challenges of such kind of synergism. There are separated different levels of synergy. Upon analysis of the industrial and postindustrial age achievements in both of the areas, there can be determined three main levels of synergetic interrelations: inspiration, application, participation. As novel materials and selection tools develop and the area of their possible architectural application increases, the synergistic effects are predicted to strengthen.
\end{abstract}

Keywords: synergy, architecture, materials science, synergetic interaction, inspiration, application, participation.

\section{Introduction}

Synergy (also synergism) is defined as "a combined power of a group of things when they are working together which is greater than the total power achieved by each working separately" [1, p.1479]. In recent years, this term became rather common to reflect the combined effects from the actions in different fields.

There are different areas of science and art that make influence on architecture. Materiality is an integral aspect of it. The interrelation between material itself as a "physical substance" [1, p. 882] and architecture as the "art and science of designing and making buildings" $[1$, p. 66] is a subject of many researches.

According to William Morris statement “...the subject of Material is clearly the foundation of architecture, and perhaps one would not go very far wrong if one defined architecture as the art of building suitably with suitable material" [2]. The interrelation between material and architectural form is discovered in the work by Richard Weston [3]. Searching for the essence "in the nature of materials" [3, p. 68-97; 4, p. 128-129] confirm Morris conclusion about serving each material to a specific purpose. In the works by D. Michelle Addington and Daniel L. Schodek on smart materials for architecture [5] and John Fernandez [6] on selection tools of materials for architecture there is discussed the attitude of architects and engineers to materials in modern conditions. There are some works devoted to the methodology of material exploration in architectural process [7].

The most of the researchers, emphasizing on the strong links between architecture and material, do not consider synergism or just pay attention to the separate examples of 
this phenomenon. Whereas, contemporary architects involve new materials, discovered and designed by materials scientists or even participate in the process of their development. Therefore, attention should be paid to the synergism between architecture as an art and science and materials science as interdisciplinary scientific field. The most detailed and complete latest research on synergies of architecture and materials science was conducted by Sascha Bohnenberger [8]. In this work, he concluded that "synergies between architecture and science < are> more limited".

\section{Aim and scope of the research}

The aim of the research was the determination the basic levels of synergetic interaction between architecture and materials science. The changes with time and influence of different factors on this process are discovered.

\section{Peculiarities of interaction between architecture and materials science}

The interrelation between these two fields varied greatly depending on the level of industrial development of society and change of architectural paradigms (Fig.1).

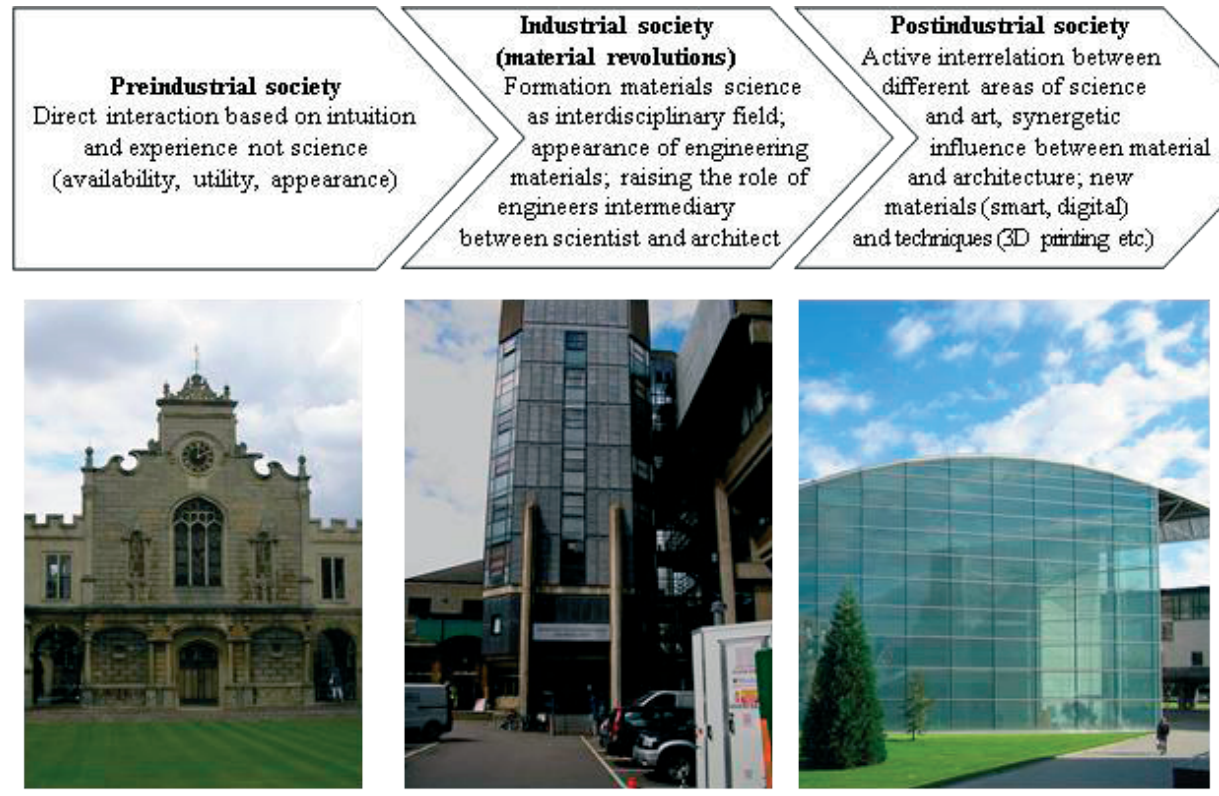

Fig. 1. Relation between material and architecture at the ages of preindustrial, industrial and postindustrial society based on the data of Addington and Schodek [5], Fernandez [6], Ashby and Johnson [9]. From left to right: Peterhouse -the oldest of Cambridge Colleges, Cambridge, UK, est. in 1284 entrance part; photo by N. Lushnikova; Arup Tower at New Museums Site (former building of the Department of Materials Science and Metallurgy, completed in 1971), University of Cambridge (photo by N. Lushnikova); Squire Law Library, Law Faculty, University of Cambridge, designed by Foster and Partners and completed in 1995 (photo by Andrew Dunn, source: https://commons.wikimedia.org/wiki/File:Law_Faculty_University_of_Cambridge.jpg) 
The degrees of architect's freedom in selection of material increased with time. In Preindustrial Age the relation between material and architecture was primitive. The form followed the available and workable material [5], mostly natural or low-quality artificial one, searching for proper construction technique was rather intuitive and experimental [8]. Materials science formed as separate field due to the successes in technological achievements upon new industrial materials appearance (steel, concrete, glass) during Industrial Revolution [8]. In Industrial Age materials science was separated as a discipline and role of engineer as a person able to select rationally rose. After Louis Sullivan "Form follows function" late industrial and postindustrial architects and scientists enounced the formula "Form follows material" [9]. In one of the essay, Frank Lloyd Wright stated "Every new material means a new form, a new use if used according to its nature' [10].

During industrial and postindustrial ages the distance between materials science and architecture tends to enlarge due to the intermediate members - representatives of engineering fields (Fig. 2). Materials science and engineering are often form integrity as well architectural engineering as the application of engineering principles to building design and construction unites civil engineering and architecture. Civil engineering unites materials and architectural engineering thus, normally it does not deal with aesthetics but with function of material and building as well.

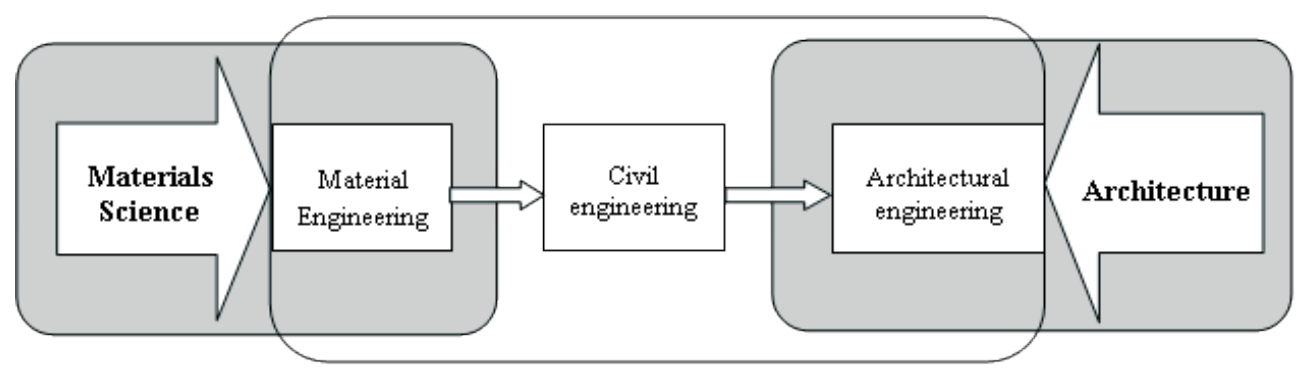

Fig. 2. Interaction between materials science and architecture

The lack of the direct interrelation between materials scientist and architect is still the main obstacle to the synergetic effects of their work [4,6], as there are different worldviews of materials science and architecture [8]. The main obstacles in synergy between science and architecture is difference in the approaches and methods, and even object of studying (from atom-molecule and microscales in materials science through macro scale in architecture to megascale in urban planning). That partly can explain the differences in orientations for scientists and designers starting from their studying. Mike Ashby sets science-driven and design-driven approaches in teaching (Fig. 3) [11]. First one, based on moving from atomic structure to the product (a building in our case), is traditional for scientists, the second one goes in opposite way from a finite product (architectural form in our case) to the essence of a material applied. That confirms the fact that scientists are "concerned with how things are" whereas designers are "concerned with how things ought to be" [8].

In modern conditions the science-driven approach in teaching architects and movement from material, as quotient, to architecture, as general, is common in many countries, for instance in Eastern Europe [12]. 


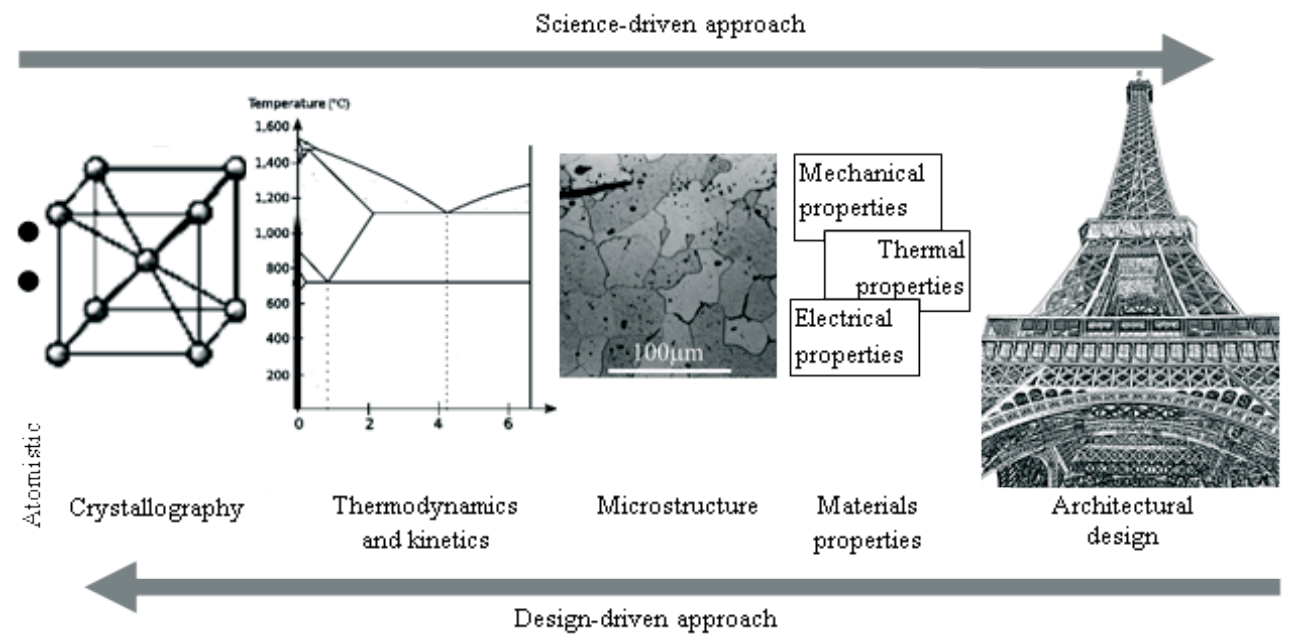

Fig. 3. Design-driven and science-driven approaches as opposite (adopted version according to Ashby [11]). The pictures from the following sources are used: https://en.wikipedia.org/wiki/Austenite; http://core.materials.ac.uk/repository/doitpoms/miclib/000218.jpg; http://www.stockpicturesforeveryone.com/2011/09/eiffel-tower-sketches-and-silhouettes.html

Another important issue is that materials scientist on developing the material does not always realize the application area. At the same time, more and more materials appear every day but architects feel the lack of information about them. Architect, as any designer, is more obsessed with materials "psychology", the application context, personality of product "derived from its aesthetics, associations and perceptions" [9]. Bohnenberger separates intrinsic properties of a material, related to its atomic structure and include mechanical, physical, thermal and optical properties and extrinsic properties related often to the context of the material application (economic, environmental and societal properties). In the case of novel material, these properties are unknown to the architect [8].

Regardless the substantial differences in the way of thinking, designers and scientist use similar methods for studying micro- and mega-objects (modeling, prototyping). At the same time term 'architecture' is widely applied in the science as a synonym of structure, of order. For some architects inspired by the scientific achievements pass allusions from chemical and physical processes to architecture. Architect, designer and inventor William Katavolos stated in the beginning of 1960's: "A new architecture is possible through the matrix of chemistry. Man must stop making and manipulating, and instead allow architecture to happen" [13]. Peter Zumtor says about one of his project: "We actually never talk about form in the office. We talk about construction, we can talk about science, and we talk about feelings [...] From the beginning the materials are there, right next to the desk $[\ldots]$ when we put materials together, a reaction starts $[\ldots]$ this is about materials, this is about creating an atmosphere, and this is about creating architecture" [14]. 


\section{Levels of synergism between architecture and materials science}

Inventions new materials and innovations in materials science inspire architects. The relationship between architecture and materials science is to be two-way: "architecture introduces ideas from science to generate new design and science uses architectural principles to communicate ideas" $[8,15]$. Therefore, we can discuss the inspiration as one of synergetic effect in interaction of materials science and architecture. Often we can observe synergy in world fairs pavilions as embodiment of the latest developments in different areas.

At the level of inspiration, the small scales developments of materials science become apparent in conceptual architectural projects. That was the most evident during the postwar period successes of scientists. In this way, for instance, Atomium in Brussels by engineer Andre Waterkeyn and architects Andre and Jean Polak, constructed initially for Expo'58, visualizes crystal lattice of iron (Fig. 4). The opposite inspiration of science by architectural form can be observed in the following example. The Montreal Biosphere designed by Buckminster Fuller, former pavilion of the United States for Expo'67 and his geodesic domes inspired scientists to name spherical molecule of fullerenes after him Buckminsterfullerene (Fig. 5 upper pictures). In its turn, Nicholas Grimshaw implements further inspiration with geodesic domes in Eden project where ETFE pillows were applied as novel constructive elements (Fig. 5, bottom picture).

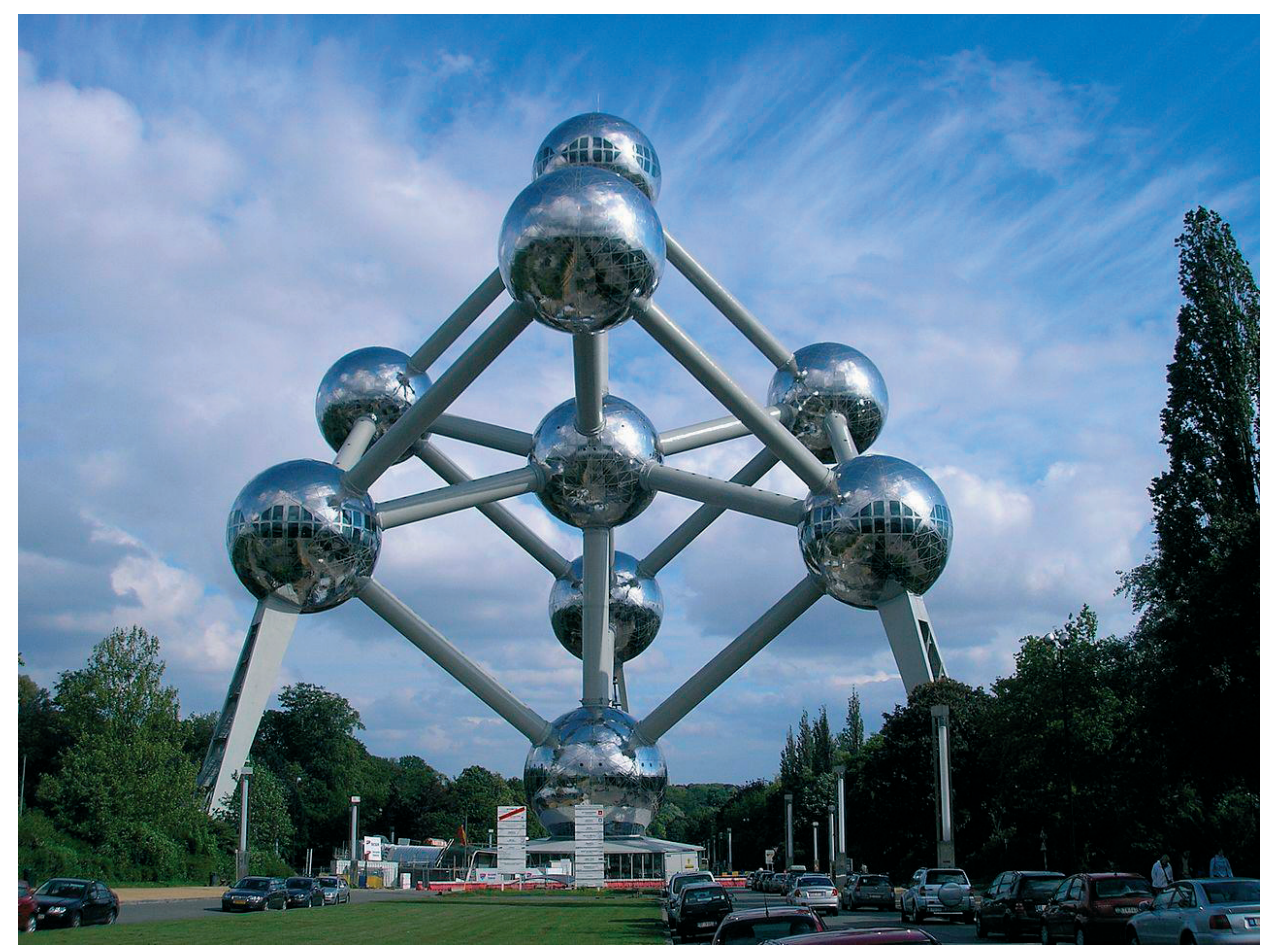

Fig. 4. Atomium in Brussels by engineer Andre Waterkeyn and architects Andre and Jean Polak, constructed initially for Expo'58. Source:

https://ru.wikipedia.org/wiki/Атомиум\#/media/File:Atomium_w_Brukseli.JPG. 

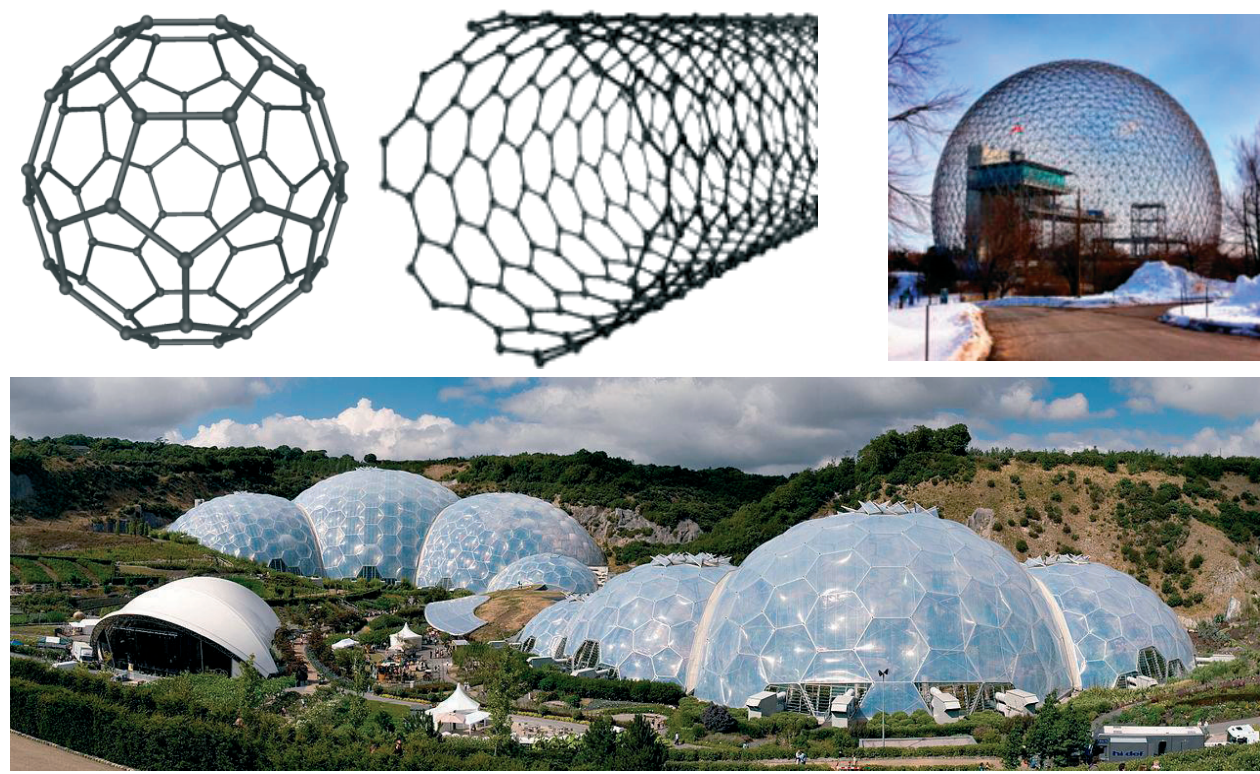

Fig. 5. Synergism in inspiration: architect inspires and inspired by materials science. Up from left to right: Buckminsterfullerene C60 - member of fullerene family carbon molecule, named after Buckminster Fuller -the author of geodesic sphere.

https:/en.wikipedia.org/wiki/Fullerene\#/media/File:C60a.png;

Nanotube - cylindrical nanostructure of carbon as new chemical structure member of fullerene family, source:

https://upload.wikimedia.org/wikipedia/uk/c/c2/250px-Nanotube_6_9-spheres.jpg;

Montreal Biosphere, the former Expo 67 United States of America Pavilion designed by Buckminster Fuller, Montreal's Parc Jean-Drapeau, source:

https://commons.wikimedia.org/wiki/File:Montreal_Biosphere.JPG.

Bottom: Panoramic view of the geodesic biome domes at the Eden project designed by Nicholas Grimshaw, Photo by Jürgen Matern, source:

https://upload.wikimedia.org/wikipedia/commons/f/f2/Eden_Project_geodesic_domes_panorama.jpg

The most common demonstration of synergism is the application of the newest materials science innovations in architecture. We remember Frank Lloyd Wright as a pioneer in application advanced composites. He was one of the first architects to apply translucent fiberglass panels (GFRP) in his residence Taliesin West in Scottsdale, Arizona, 1937. Sandwich panels with translucent silica aerogel insulation, which has extremely low density and high thermal properties, Thomas Herzog applied for his residential building project in Munich in 1994 (Fig. 6). There is a tendency in application in architecture of novel materials which were initially designed for other purposes. There can be emergent materials primarily applied in other areas (advanced and smart materials), databases of new materials created etc.

At the level of participation, the architect becomes an active participant of materials' invention. The main reason for that is the absence on the market the material required for certain design purpose. However, there can be other reasons. Russian-Soviet avant-garde architect and scientist Andrei Burov came to research after some disappointments in the architectural activity. Being a developer the technology of synthetic materials (glass fiber reinforced plastics) he designed the residential building with envelopes made of plastic (Fig. 7). Hungarian architect Áron Losonczi became much more famous for the invention of light-transmitting concrete - cement based concrete with optical fiber (Fig. 7). 

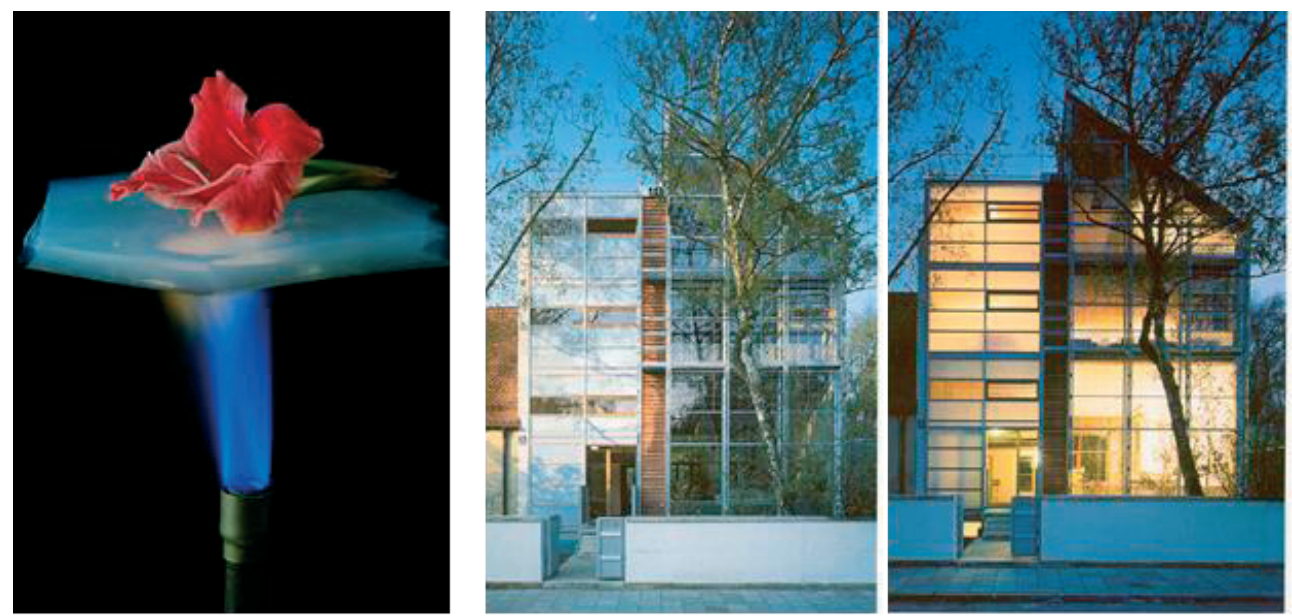

Fig. 6. Synergism in application: architect as a pioneer in using materials science developments. From the left to the right: a flower is on a piece of aerogel supported by the flame from a Bunsen burner; Public domain. Source:

https://en.wikipedia.org/wiki/Aerogel\#/media/File:Aerogelflower_filtered.jpg;

Translucent envelopes with high thermal resistance of the apartment building in Munich, Germany 1994, designed by Thomas Herzog, Architect; Source: Ashby M. Fernandez J. Unit 15. Architecture \& Built Environment: materials for construction. Source:

http://teachingresources.grantadesign.com/Architecture
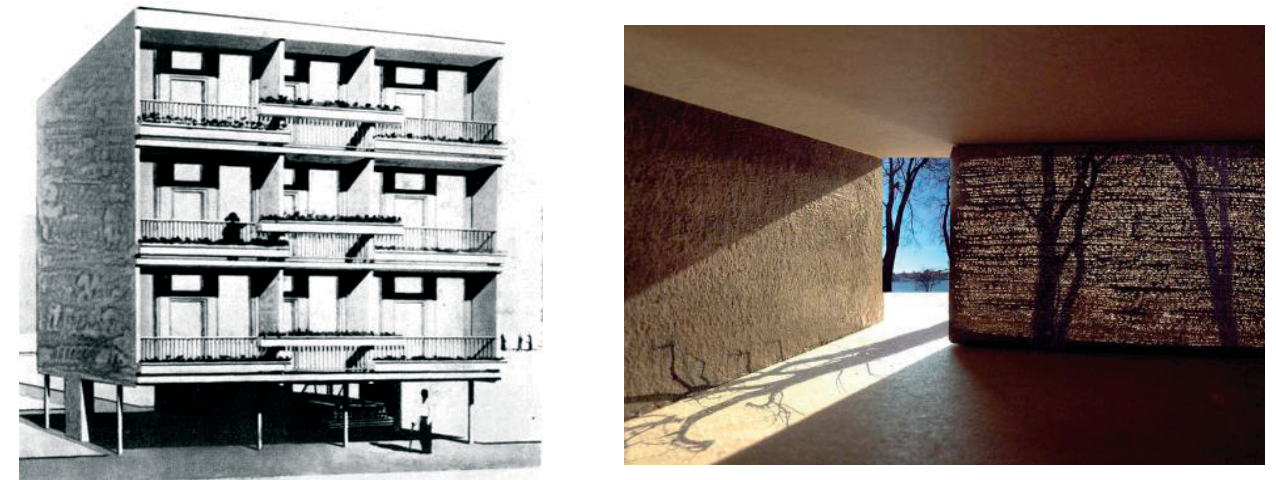

Fig. 7. Synergism in participation: architect as a materials scientist. To the left: residential house with envelopes made of glass-fiber reinforced material; designed by A. Burov - a co-inventor of glassfiber reinforced material, 1956, Source: http://famous.totalarch.com/burov. To the right: main entrance door of Museum Cella Septichora made of $10 \mathrm{~cm}$ thick Litracon Classic blocks, 2006, Pécs, Hungary; Bachmann Architects (right). Source:

https://www.flickr.com/photos/eager/15739911236.

The participation of architect in the creation of new materials can also serve not only intentional but also educational purposes. Images by Professor Richard Weston derived from the micro level of natural materials and enlarge to architecturally applicable sizes. One of such samples is laminated silk panels for facades (Fig. 8). 

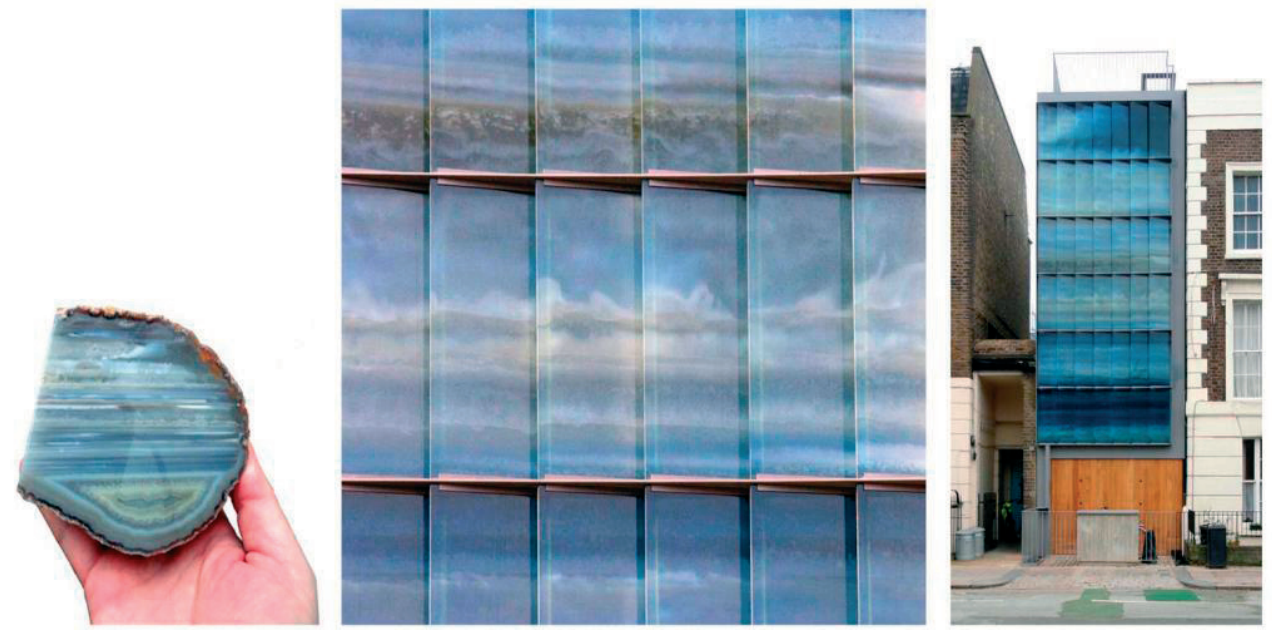

Fig. 8. Synergism in participation: architect as a materials scientist. Level-bedded agate texture digitally printed onto silk habotai by Maver in Italy and then laminated into glass by Hourglass in Hampshire. Designed by Richard Weston, applied as façade panels in Camden House, London, by architect Patel Taylor, 2010. Pictures are given by Professor Richard Weston.

\section{Conclusions}

Regardless of the challenges and lack of direct communication between materials scientist and architecture, the contemporary architectural objects are the results of synergism with material. Upon analysis of the synergetic links there can be separated several levels of synergism: level of inspiration when architects are inspired with materials science achievements and vice versa; level of application - the widest spread - when architects apply novel materials in their projects and level of participation when architect takes an active part in development new materials for specific design needs.

One of the possible ways to bridge the gap between the architect and materials science at the stage of education and practical work is development special courses assigned for approaching the specialists. Another way is spreading the reliable and easy readable information about new materials properties, e.g. software for rational selection of a material.

Due to the development of new techniques for construction (e.g. 3D printing), simplification the methods of materials application, need in new design approaches to new materials the synergetic effect in this fields is supposed to grow with time.

\section{References}

1. Cambridge Advanced Learner's Dictionary. $3^{\text {rd }}$ Edition Cambridge University Press, Cambridge 2008.

2. Morris W. The influence of building materials on architecture, $20^{\text {th }}$ November 1891 at a meeting sponsored by the Art Workers' Guild at Barnard's Inn, London. Published by Century Guild Hobby Horse, 1892. https://www.marxists.org/archive/morris/works/1891/building.htm.

3. Weston R. Materials, form and architecture. Yale University Press, New Haven 2003. 
4. Weston R. 100 ideas that changed architecture. Lawrence King Publishing Ltd., London 2011.

5. Addington D.M., Schodek D.L. Smart materials and new technologies for the architecture and design professions. Architectural Press, Oxford 2005.

6. Fernandez J. Material architecture. Emergent materials for innovative buildings and ecological construction. Architectural Press, Oxford 2006.

7. Borden G.P., Meredith M. (Ed.) Matter. Material processes in architectural production. Routledge, New York 2012.

8. Bohnenberger S. Material exploration and engagement. Strategies for investigating how multifunctional materials can be used as design drivers in architecture. $\mathrm{PhD}$ Thesis MIT University, Melbourne, Australia, 2013.

9. Ashby M., Johnson K. Materials and design. The art and science of material selection in product design. 2nd ed. Butterworth-Heinemann, Oxford 2010.

10. Wright F.L., Devane A., Gutheim F.A. In the cause of architecture. Frank Lloyd Wright: essays. Architectural Record, 1975.

11. Ashby M. Teaching materials and processes to first and second year students. White Paper. MFA, 04/09/2007. http:/www.grantadesign.com/download/pdf/First_Second_Year_Courses.pdf.

12. Lushnikova N. Materials related courses for architecture students: Ukrainian experience. Poster on VI Materials Education Symposia "Materials, Systems, Innovation, and Sustainable Development", Sub-theme 1: Materials across Disciplines. Architecture, University of Cambridge April 10-11, 2014.

13. Katavolos W. Organics. [Quadrat-Print / Quadrat-Blatt / Feuilles-Cadrat / Kwadraat Blad] Hilversum: Steendrukkerij De Jong \& Co, 1961.

14. Merin G., Zumthor P. Seven personal observations on presence in architecture. 03 December, 2013. Available at: http://www.archdaily.com/452513/peter-zumthor-seven-personalobservations-on-presence-in-architecture.

15. Ng Rashida. Something Borrowed: Defining an Emerging Covenant between Architecture and Materials. ARCC/EAAE Proc. of International Conference on Architectural Research, 2010/ Available at: http://www.aia.org/aiaucmp/groups/aia/documents/pdf/aiab087168.pdf

\title{
Synergia \\ architektury współczesnej i inżynierii materiałowej
}

\author{
Petro Rychkov ${ }^{1}$, Nataliya Lushnikova ${ }^{2}$ \\ ${ }^{1}$ Katedra Konserwacji Zabytków, Politechnika Lubelska, Lublin, \\ e-mail:p.rychkov@pollub.pl \\ ${ }^{2}$ Katedra Architektury i Projektowania Środowiska, \\ Narodowy Uniwersytet Gospodarki Wodnej i Zasobów Przyrody, Riwne, Ukraina, \\ e-mail:n.v.lushnikova@nuwm.edu.ua
}

Streszczenie: Artykuł daje zasięg na poziomie synergicznego współdziałania architektury i inżynierii materiałowej. Omówiono niektóre główne korzyści i problemy związane z takim synergizmem. Różne poziomy synergii są podzielone w zależności od różnych kryteriów. Po analizie osiągnięc materialnych społeczeństwa przemysłowego i poprzemysłowego można określić trzy główne poziomy synergicznych powiązań: inspiracja, aplikacja, partycypacja. Ponieważ nowe materiały i narzędzia selekcji tych 
materialów są zwększone i obszar możliwych zastosowań architektonicznych wzrostają, efekty synergiczne rownież przewiduje wzmocnienie.

Słowa kluczowe: synergia, architektura, inżynieria materiałowa, synergiczne działanie, inspiracja, aplikacja, partycypacja. 